\title{
Water heater temperature set point and water use patterns influence Legionella pneumophila and associated microorganisms at the tap
}

\author{
William J. Rhoads ${ }^{*}$ Pan Ji, Amy Pruden and Marc A. Edwards
}

\begin{abstract}
Background: Lowering water heater temperature set points and using less drinking water are common approaches to conserving water and energy; yet, there are discrepancies in past literature regarding the effects of water heater temperature and water use patterns on the occurrence of opportunistic pathogens, in particular Legionella pneumophila. Our objective was to conduct a controlled, replicated pilot-scale investigation to address this knowledge gap using continuously recirculating water heaters to examine five water heater set points $\left(39-58^{\circ} \mathrm{C}\right)$ under three water use conditions. We hypothesized that L. pneumophila levels at the tap depend on the collective influence of water heater temperature, flow frequency, and the resident plumbing ecology.

Results: We confirmed temperature setting to be a critical factor in suppressing L. pneumophila growth both in continuously recirculating hot water lines and at distal taps. For example, at $51{ }^{\circ} \mathrm{C}$, planktonic L. pneumophila in recirculating lines was reduced by a factor of $28.7 \mathrm{compared}$ to $39^{\circ} \mathrm{C}$ and was prevented from re-colonizing biofilm. However, L. pneumophila still persisted up to $58^{\circ} \mathrm{C}$, with evidence that it was growing under the conditions of this study. Further, exposure to $51{ }^{\circ} \mathrm{C}$ water in a low-use tap appeared to optimally select for L. pneumophila (e.g., 125 times greater numbers than in high-use taps). We subsequently explored relationships among L. pneumophila and other ecologically relevant microbes, noting that elevated temperature did not have a general disinfecting effect in terms of total bacterial numbers. We documented the relationship between L. pneumophila and Legionella spp., and noted several instances of correlations with Vermamoeba vermiformis, and generally found that there is a dynamic relationship with this amoeba host over the range of temperatures and water use frequencies examined.
\end{abstract}

Conclusions: Our study provides a new window of understanding into the microbial ecology of potable hot water systems and helps to resolve past discrepancies in the literature regarding the influence of water temperature and stagnation on L. pneumophila, which is the cause of a growing number of outbreaks. This work is especially timely, given society's movement towards "green" buildings and the need to reconcile innovations in building design with public health.

Keywords: Legionella pneumophila, Hot water, Stagnation, Water use, Temperature

\footnotetext{
* Correspondence: wrhoads@vt.edu

Charles E. Via Department of Civil and Environmental Engineering, Virginia Tech, Blacksburg, VA 24061, USA
} 


\section{Background}

The growth of opportunistic pathogens (OPs) in building plumbing systems is an increasing public health threat with no clear solutions [1-4]. In particular, the warm, stagnant conditions in building plumbing create ideal conditions for re-growth of a number of OPs and their free-living amoeba hosts (Additional file 1: Figure S1). Legionella spp., including L. pneumophila, are model organisms for understanding the interplay between building plumbing design and operation and OP proliferation. Legionella is now recognized as the most common agents of waterborne disease outbreak, resulting in an estimated 8000 to 18,000 hospitalizations (which are likely underreported) due to the severe pneumonia that characterizes Legionnaires' disease $[5,6]$. With communityacquired infections representing $96 \%(n=31)$ of reported drinking water-associated Legionnaires' disease outbreaks from 2007 to 2010, the majority of drinking waterassociated Legionnaires' disease cases result from exposure to aerosols from drinking water systems in the built environment. A fundamental feature of Legionella and other OPs is that they can grow and thrive as part of complex microbial communities inhabiting building plumbing supplied by "clean" drinking water and therefore do not necessarily respond to traditional approaches for pathogen control geared towards fecal organisms [7, 8]. At the same time, the characteristic conditions in building plumbing (e.g., warm temperature, high surface area, and long residence time) make it difficult to maintain an effective chlorine residual usually depended upon to kill pathogens $[3,9,10]$. Thus, new strategies are needed for building plumbing design and operation that are informed by how they influence Legionella and its microbial ecology.

Prior field studies provide some clues about key factors that trigger Legionella colonization and amplification in building plumbing [11-13]. Legionella is notorious for growing in hot water systems, and while the optimal temperatures for inhibiting its growth have been well characterized in laboratory culture, they are not necessarily applicable to field conditions where $L e$ gionella colonizes biofilm and may be protected within an amoeba host [14]. Further, water heater set points do not directly translate into the temperature experienced at the tap, where it can quickly cool to room temperature.

Stagnation has also received a great deal of attention as a major risk factor for Legionella amplification and is interrelated with temperature setting [15-23]. For example, an advantage of recirculating systems is that they maintain water temperature in the recirculating pipes closer to the water heater temperature, which will ideally kill Legionella and prevent further colonization. Although the majority of guidance criteria advise against stagnation [17-19, 22], prior reports are inconsistent and indicate that it sometimes stimulates [15] and sometimes deters [23-25] Legionella growth. In the absence of disinfectant (thermal or chemical), stagnation may limit the delivery of new nutrients to distal taps, reducing the potential for re-growth $[23,26]$. However, nutrient gradients have not been examined in an integrated fashion considerate of how plumbing temperature and water use conditions together might ultimately impact nutrient availability. Finally, given that Legionella and many other OPs are intimately dependent on host freeliving amoebae for their replication in oligotrophic drinking water systems, better understanding this ecological relationship as influenced by temperature and stagnation is critical [14, 27, 28].

A major limitation of field studies is the inherent complexity encountered in actual building systems, which make it difficult to pinpoint precise factors that trigger Legionella proliferation. Therefore, our objective was to conduct a controlled, replicated laboratory investigation examining the interrelationship of water heater temperature set point and distal tap use frequency on Legionella occurrence. Identical experimental and control hot water plumbing systems were constructed in which continuously recirculating pipe loops delivered water to distal taps subject to high, medium, and low water use frequency (Fig. 1). Both systems were initially acclimated for 5 months at $39^{\circ} \mathrm{C}$ to establish a baseline with stable microbial communities before incrementally increasing the water heater temperature of the experimental system to $42,48,51$, and $58{ }^{\circ} \mathrm{C}$, while the control system was maintained at $39{ }^{\circ} \mathrm{C}$ for the duration of the 15-month experiment. Genetic markers of Legionella spp. (23S ribosomal RNA (rRNA) gene), L. pneumophila (macrophage infectivity potentiator (mip) gene), Vermamoeba vermiformis (18S rRNA gene; an important ecological host for Legionella), and total bacteria (16S rRNA gene) were tracked by quantitative polymerase chain reaction (q-PCR) to measure re-growth in the recirculating lines relative to the influent water and in distal taps relative to the recirculating lines (Fig. 1). Given the current trend towards "green" buildings that are intended to conserve both water (i.e., to decrease water use frequency, which increases corresponding stagnation) and energy (i.e., lower temperature settings), the present moment is critical for untangling the complexities that trigger Legionella growth and identifying practical solutions for their control that can be considered in building system design.

\section{Results and discussion}

Both Legionella spp. and L. pneumophila naturally colonized both the experimental and control building plumbing systems and established a comparable baseline, which provided the unique opportunity to systematically 


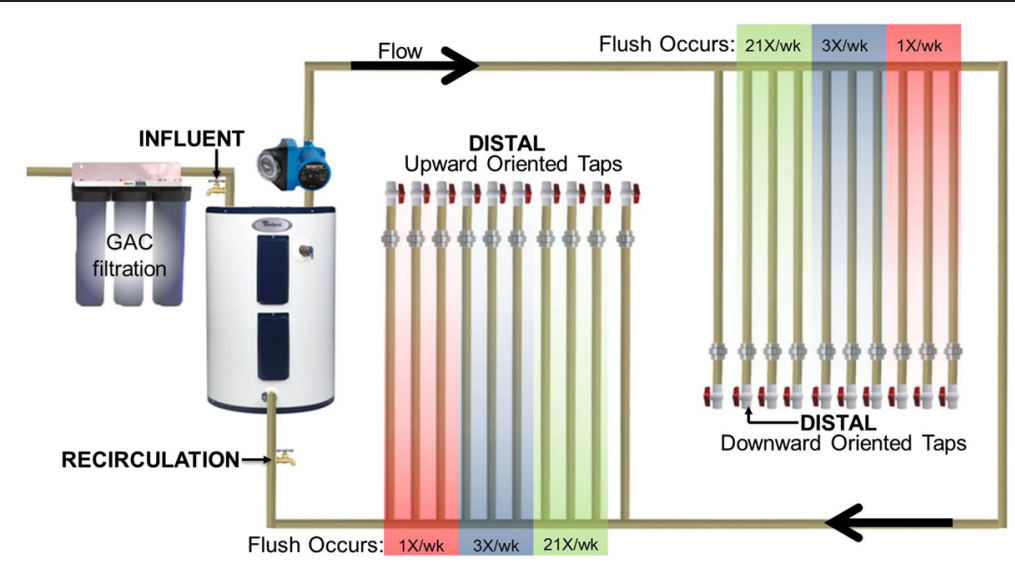

Fig. 1 Overview of experimental design of replicated building plumbing systems. Two identical systems were constructed to examine the effect of water heater temperature setting and water use frequency on Legionella proliferation. One remained at $39^{\circ} \mathrm{C}$ (control system) while the other was incrementally increased to $58^{\circ} \mathrm{C}$ (experimental system) over 15 months. Influent water was flushed through three granular activated carbon whole-house filters (sample port Inf), a recirculating pump continuously pumped water around the return loop back to the water heater creating a completely mixed reservoir (sample port Recirc), and six replicate distal taps (three upward + three downward) were flushed at $3.8 \mathrm{~L} / \mathrm{min}(1 \mathrm{gallon} / \mathrm{min}$ ) 21 times/week, 3 times/week, and 1 times/week for a total of 36 pipes (sample ports: at end of distal pipes)

examine the effect of changes in building plumbing operation and microbial response under replicated and controlled conditions. Our overarching hypothesis was that $L$. pneumophila levels at the tap depend on the interrelationship between water heater temperature set point and use frequency and their collective influence on the microbiome. Table 1 breaks this hypothesis down more specifically, summarizing four representative conditions (I-IV) under which increased use frequency would be expected to increase, decrease, or have no effect on L. pneumophila levels. Across this study, we conducted testing with little to no disinfectant residual, as can occur in building plumbing, especially under water conservation scenarios and at the end of water main networks [29-32]. If disinfectant can be effectively delivered and maintained above about $0.5 \mathrm{mg} / \mathrm{L}$ as $\mathrm{Cl}_{2}$ (condition IV), it is generally believed that $L$. pneumophila will effectively be controlled $[18,22]$. In the following sections, we first discuss physicochemical trends in temperature and chlorine and subsequently examine occurrence of L. pneumophila and other ecologically relevant microbes relative to these trends and in the context of the specific hypotheses presented in Table 1. Table 2 provides an overview of the calculations we employed in this study to compare the distribution of L. pneumophila between the experimental and control rigs and across various system compartments.

\section{Physicochemical trends Distal pipe temperatures}

We documented a clear disconnect between water heater set point and temperatures observed at the distal taps. Water at the distal taps cooled to room temperature $\left(26.1 \pm 0.2{ }^{\circ} \mathrm{C}\right)$ within $25 \mathrm{~min}$ of each water use event, regardless of water heater set point temperature (Fig. 2). In general, water in the distal taps never exceeded the temperature $\times$ time requirements to achieve $99 \%$ disinfection of Legionella. Stagnation temperature differed by only $\sim 1{ }^{\circ} \mathrm{C}$ (Additional file 1 :

Table 1 Hypothesized effects of increased water use frequency under various hot water system operating conditions on $L$. pneumophila in distal taps

\begin{tabular}{|c|c|c|c|}
\hline Condition $^{a}$ & Dominant impact & Hypothesized result & Experiment herein \\
\hline $\begin{array}{l}\text { I. No disinfectant and low water } \\
\text { heater set point }\left(T<48^{\circ} \mathrm{C}\right)\end{array}$ & $\begin{array}{l}\text { Growth due to increased delivery of } \\
\text { nutrients to distal taps at ideal growth } T\end{array}$ & $\begin{array}{l}\text { Greatest total numbers produced in distal taps } \\
\text { with time but lower concentrations due to } \\
\text { more frequent use }\end{array}$ & $\begin{array}{l}\text { Control system, over } \\
\text { time }\left(T=39^{\circ} \mathrm{C}\right)\end{array}$ \\
\hline $\begin{array}{l}\text { I. No disinfectant and moderate water } \\
\text { heater set point }\left(T=48-51^{\circ} \mathrm{C}\right)\end{array}$ & $\begin{array}{l}\text { Low-use condition provides optimal } \\
\text { ecological selection by transient sub- } \\
\text { lethal } T \text { events }\end{array}$ & $\begin{array}{l}\text { Lower numbers produced in distal taps and } \\
\text { lower concentrations at higher use }\end{array}$ & Exp. $2\left(T=51^{\circ} \mathrm{C}\right)$ \\
\hline IV. Stable and high disinfectant & Disinfection effect dominates & Lower number and concentrations & $\begin{array}{l}\text { Not tested in this } \\
\text { work }\end{array}$ \\
\hline
\end{tabular}


Table 2 Calculations for determining L. pneumophila distribution across various system compartments and effects of operating conditions

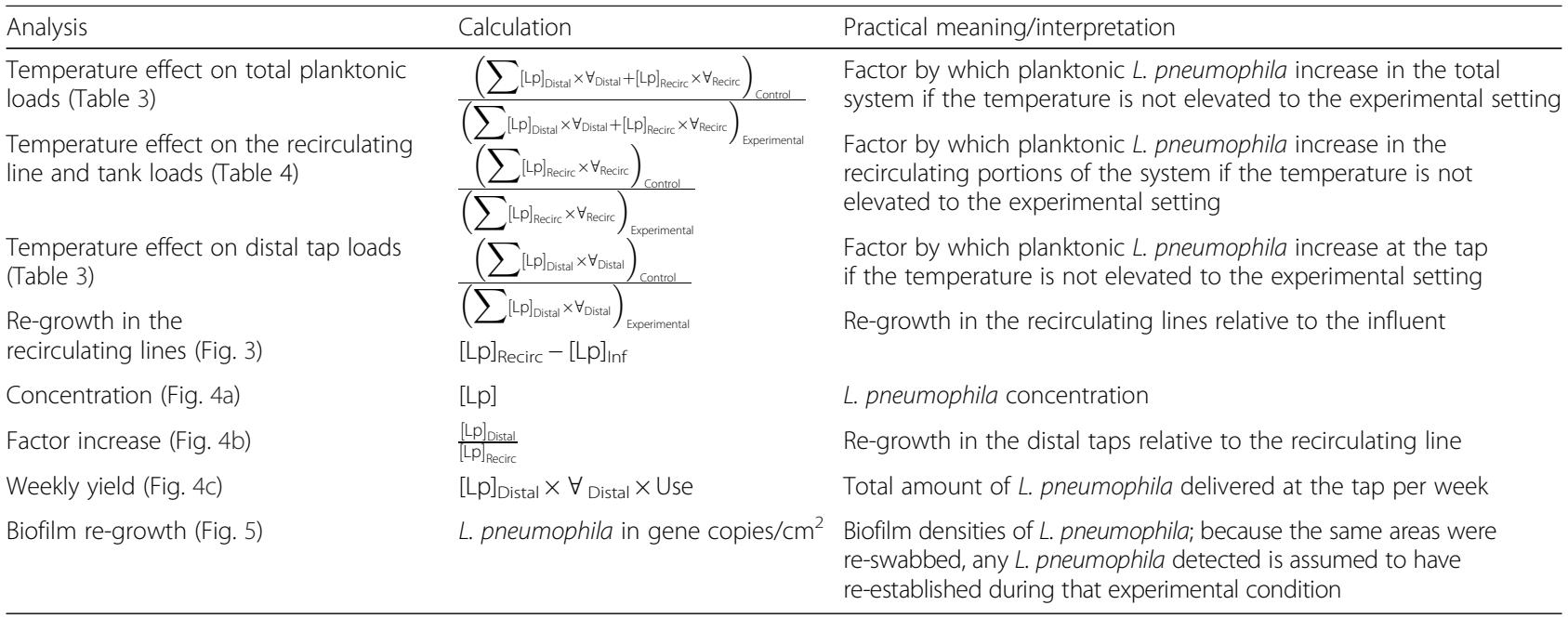

Lp: L. pneumophila concentration in gene copies/mL, Distal distal tap, Recirc recirculating line and tank, $\forall$ volume, Inf influent, Use use per week (21, 3, or 1)

Figure S2), and Legionella spp. and L. pneumophila levels were not significantly different in upward versus downward oriented pipes (paired $t$ test, $n=177, p$ value $=0.48$ and 0.31 , respectively), so these data were pooled for subsequent analysis, resulting in six replicates for each water use frequency.

\section{Total chlorine}

Chloramine was removed from influent Blacksburg, VA, drinking water using three granular activated carbon filters (Pentek, Upper Saddle River, NJ). Average total

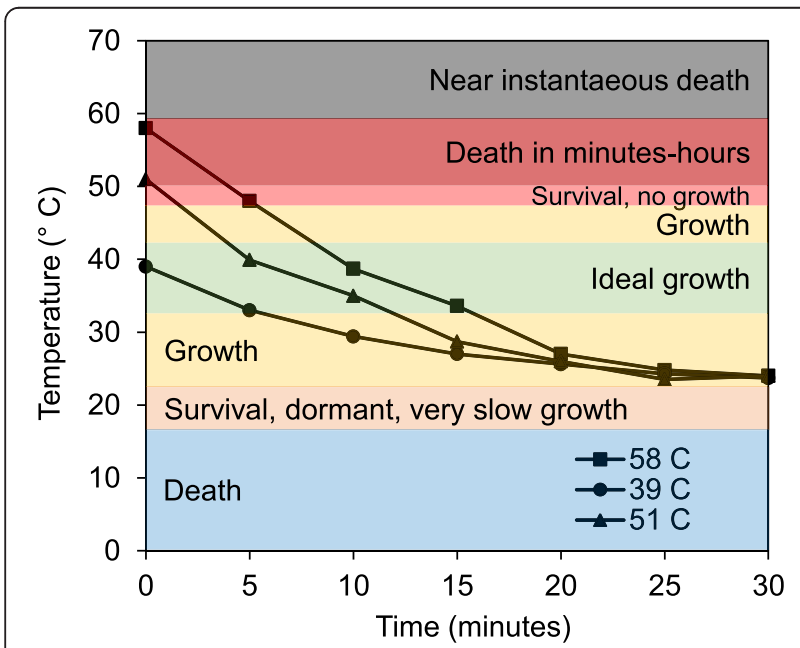

Fig. 2 Water temperatures (and reported effects on Legionella) at distal taps with stagnation time. Targeted water temperatures were not maintained in pipes for sufficient durations after each use to effectively disinfect Legionella. Shaded temperature regions labeled on the plot represent the time required to achieve $90 \%$ inactivation of Legionella. (time to $90 \%$ death and growth temperature ranges based on references [42-48]) chlorine concentrations in the influent water samples were always less than $0.10 \mathrm{mg} / \mathrm{L}$ as $\mathrm{Cl}_{2}$ and remained near the detection limit $\left(0.02 \mathrm{mg} / \mathrm{L}\right.$ as $\left.\mathrm{Cl}_{2}\right)$ in the water heaters throughout the experiment (Additional file 1: Figure S3). Therefore, we achieved the goal of eliminating disinfectant from the system, which we hypothesize would have overridden the effects of temperature and water use that are the focus of this study (Table 1).

\section{General trends in L. pneumophila occurrence and effect of water heater temperature}

L. pneumophila was found to naturally colonize the systems at comparable levels following the 5-month baseline conditioning at $39{ }^{\circ} \mathrm{C}$ (Table 3), which facilitated subsequent comparisons throughout the study. Further, elevated levels of $L$. pneumophila in the recirculating lines relative to the influent across all samplings confirmed that at least some portion of the L. pneumophila detected was actively re-growing in the building plumbing and not just passing through from the influent water (Fig. 3, 1.7-3.5 logs higher in the recirculating lines; Kruskal-Wallis test, $p$ value $=0.002-0.035$, except the control system baseline sampling, $p$ value $=0.11$, and the experimental system at $51{ }^{\circ} \mathrm{C}, p$ value $=0.080$ ). Unless otherwise stated, we focus our discussion here on the behavior of planktonic L. pneumophila, which is ultimately what consumers will be exposed to in buildings, and later describe what was observed with respect to other target microbes and in the biofilm.

Generally, it was found that L. pneumophila decreased as the water heater temperature setting increased, as was apparent in comparing levels in the control versus experimental recirculating lines (Fig. 3). More detailed comparisons were made by normalizing the levels of $L$. 
Table 3 Average total number of planktonic L. pneumophila gene copies in each reservoir during each sampling (for each sampling, $n=18$ for distal taps; $n=2-6$ for tank + recirc)

\begin{tabular}{|c|c|c|c|c|c|}
\hline System & Reservoir & $\begin{array}{l}\text { Baseline } \\
\text { (5 months) }\end{array}$ & $\begin{array}{l}\text { Exp. } 1 \\
\text { (8 months) }\end{array}$ & $\begin{array}{l}\text { Exp. } 2 \\
\text { (13 months) }\end{array}$ & $\begin{array}{l}\text { Exp. } 3 \\
\text { (15 months) }\end{array}$ \\
\hline \multirow[t]{2}{*}{ Control (always $39^{\circ} \mathrm{C}$ ) } & Distal taps (water) & $5.01 E+07$ & $3.02 \mathrm{E}+07$ & $1.02 \mathrm{E}+08$ & $2.17 E+08$ \\
\hline & Tank + recirc (water) & $1.30 E+09$ & $2.94 \mathrm{E}+08$ & $7.55 E+08$ & $1.55 E+09$ \\
\hline \multirow[t]{2}{*}{ Experimental } & Distal taps (water) & $5.60 \mathrm{E}+07$ & $5.92 \mathrm{E}+06$ & $2.44 \mathrm{E}+07$ & $4.98 \mathrm{E}+06$ \\
\hline & Tank + recirc (water) & $3.94 \mathrm{E}+09$ & $1.55 \mathrm{E}+08$ & $2.63 \mathrm{E}+07$ & $7.12 \mathrm{E}+07$ \\
\hline \multicolumn{2}{|c|}{ Control normalized to experimental } & $39^{\circ} \mathrm{C} / 39^{\circ} \mathrm{C}$ & $39^{\circ} \mathrm{C} / 42^{\circ} \mathrm{C}$ & $39^{\circ} \mathrm{C} / 51^{\circ} \mathrm{C}$ & $39^{\circ} \mathrm{C} / 58^{\circ} \mathrm{C}$ \\
\hline \multicolumn{2}{|c|}{ Total system L. pneumophila genes (water) } & 0.30 & 2.0 & 16.9 & 23.2 \\
\hline \multicolumn{2}{|c|}{ Tank + recirc L. pneumophila genes (water) } & 0.33 & 1.9 & 28.7 & 21.8 \\
\hline \multicolumn{2}{|c|}{ Distal tap L. pneumophila genes (water) } & 0.89 & 5.1 & 4.2 & 43.6 \\
\hline
\end{tabular}

pneumophila gene copies in the control to the experimental system as an indicator of how much higher they would be without the elevated temperature intervention (Table 3). When the experimental system was set to $51{ }^{\circ} \mathrm{C}$, L. pneumophila was 28.7 times lower in the recirculating portion of the experimental system than the control system (Kruskal-Wallis test, $p$ value $=0.019, n=12$ ), but the benefits of increased temperature were not observed at the distal taps until the highest experimental temperature setting, where L. pneumophila was 43.6 times lower in distal taps in the experimental system set to $58{ }^{\circ} \mathrm{C}$ than in the control system set to $39{ }^{\circ} \mathrm{C}$ (Kruskal-Wallis

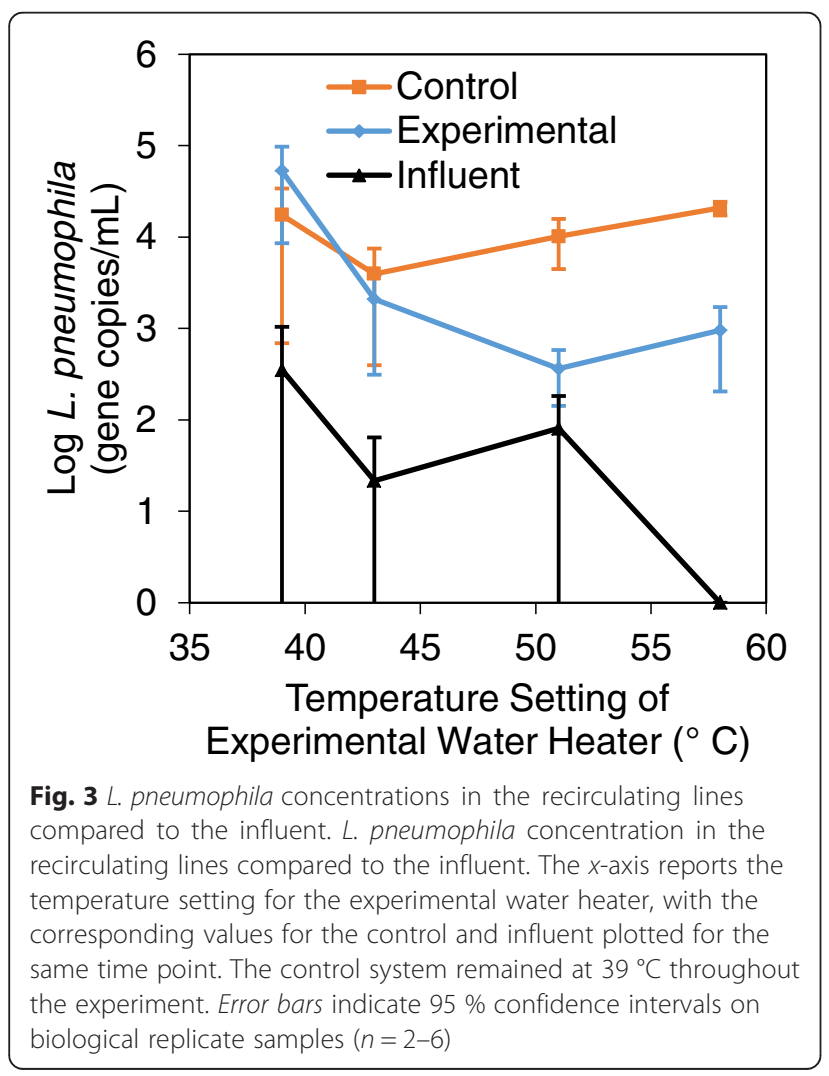

test, $p$ value $=0.0005, n=18$ ) (Table 3$)$. The overall trend illustrated that the elevated water heater temperature settings were more immediately effective in the recirculating lines, which are continuously exposed to the hot water, whereas higher temperature settings were needed to best control L. pneumophila at the tap, where the water stagnates and quickly cools.

\section{L. pneumophila in the control system and effect of use frequency (condition I)}

Examination of the control system provided the opportunity to directly evaluate the effect of water use frequency, as described in condition I (Table 1). Interestingly, we observed that there was initially little difference in the concentration of L. pneumophila (gene copies $/ \mathrm{mL}$ ) as water use frequency changed (Fig. 4a; Kruskal-Wallis test, $p$ value $=0.31-0.52$ ). However, this initial assessment can be deceiving as the actual yield of L. pneumophila at the tap (gene copies per week) typically increased by about 1 log from low use to high use because the concentrations are multiplied by the number of times per week each tap was used (Table 2; Fig. 4c). This trend was also true for the experimental system when operated at the baseline condition before the temperature was elevated. We hypothesize that this phenomenon is due to increased delivery of nutrients in the recirculating line, which broadly stimulates the microbial community in the water delivered to the distal taps. If true, this would suggest that increasing water use frequency alone will not necessarily fix a Legionella problem associated with stagnant conditions and could partially explain discrepancies in the effects of stagnation in prior reports [19, 23-25].

Comparing the distal taps to the recirculating lines is another approach to evaluate the effect of use frequency and stagnation (Fig. 4b). The L. pneumophila re-growth factor (defined in Table 2) under condition I tended to strengthen with time, indicating that L. pneumophila could become more concentrated under the stagnant 


\begin{tabular}{|c|c|c|c|c|c|c|c|}
\hline \multirow{2}{*}{$\begin{array}{c}\text { Control System } \\
\left(39^{\circ} \mathrm{C}\right)\end{array}$} & \multicolumn{3}{|c|}{ Water Use Frequency } & \multirow{2}{*}{$\begin{array}{l}\text { Experimental } \\
\text { System }\end{array}$} & \multicolumn{3}{|c|}{ Water Use Frequency } \\
\hline & Low & Medium & High & & Low & Medium & High \\
\hline 5 months & 4.2 & 4.2 & 4.1 & Baseline $\left(39^{\circ} \mathrm{C}\right)$ & 4.3 & 4.3 & 4.2 \\
\hline 8 months & 4.2 & 3.4 & 3.9 & Exp. $1\left(42^{\circ} \mathrm{C}\right)$ & 3.5 & 3.1 & 3.0 \\
\hline 13 months & 4.3 & 4.7 & 4.3 & Exp. $2\left(51^{\circ} \mathrm{C}\right)$ & 4.3 & 2.3 & 2.2 \\
\hline 15 months & 5.1 & 4.8 & 4.3 & Exp. $3\left(58^{\circ} \mathrm{C}\right)$ & 3.4 & 3.2 & 2.7 \\
\hline
\end{tabular}

B L. pneumophila regrowth factor (distal taps/recirculating lines)

\begin{tabular}{cccc|cccc} 
Control System & \multicolumn{2}{c}{ Water Use Frequency } & \multicolumn{2}{c}{ Experimental } & \multicolumn{2}{c}{ Water Use Frequency } \\
$\left(39^{\circ} \mathrm{C}\right)$ & Low & Medium & High & System & Low & Medium & High \\
\hline 5 months & 0.8 & 0.9 & 0.7 & Baseline $\left(39^{\circ} \mathrm{C}\right)$ & 0.3 & 0.4 & 0.3 \\
8 months & 4.2 & 0.7 & 2.1 & Exp. $1\left(42^{\circ} \mathrm{C}\right)$ & 1.5 & 0.5 & 0.5 \\
13 months & 1.9 & 5.6 & 1.9 & Exp. 2 $\left(51^{\circ} \mathrm{C}\right)$ & 68.2 & 0.7 & 0.6 \\
15 months & 5.5 & 3.2 & 1.0 & Exp. 3 $\left(58^{\circ} \mathrm{C}\right)$ & 2.7 & 1.6 & 0.5
\end{tabular}

C Total L. pneumophila yield per week (log gene copies)

Control System Water Use Frequency Experimental Water Use Frequency

\begin{tabular}{cccc|cccc}
$\left(39^{\circ} \mathrm{C}\right)$ & Low & Medium & High & System & Low & Medium & High \\
\hline 5 months & 6.9 & 7.4 & 8.1 & Baseline $\left(39^{\circ} \mathrm{C}\right)$ & 7.0 & 7.5 & 8.2 \\
8 months & 6.9 & 6.6 & 7.9 & Exp.1 $\left(42^{\circ} \mathrm{C}\right)$ & 6.2 & 6.2 & 7.0 \\
13 months & 7.0 & 7.9 & 8.3 & Exp. 2 $\left(51^{\circ} \mathrm{C}\right)$ & 7.0 & 5.5 & 6.3 \\
15 months & 7.8 & 8.0 & 8.4 & Exp. 3 $\left(58^{\circ} \mathrm{C}\right)$ & 6.1 & 6.4 & 6.7
\end{tabular}

Fig. 4 Heat map of L. pneumophila occurrence at the distal taps. Heat maps of L. pneumophila comparing a concentration in bulk water at each distal tap (log gene copies/mL), b distal taps normalized to the recirculating lines (re-growth factor), and $\mathbf{c}$ total yield of L. pneumophila per week at the tap (log gene copies). Colors are on a continuous scale from green (low) to red (high). Table 3 provides a detailed description of each calculation

conditions at distal taps relative to the recirculating line as a system ages. Specifically, the L. pneumophila growth factor was less than 1 for all three water use conditions at the time of the baseline sampling but increased to 5.5 and 3.2 in the low- and medium-use frequencies, respectively, by 15 months (Fig. 4b).

Monitoring the control system with time was also essential for this study in order to be certain that the trends observed in the experimental condition were a result of the temperature elevation and not necessarily natural succession of the microbial populations. Notably, L. pneumophila levels generally increased with time at the tap of the control system over the 15-month study (Table 3 , by a factor of 4.3; Kruskal-Wallis test, $p$ value $<0.0001, n=16-18$ per sampling event), especially in the low-use condition (Fig. 4a). By the end of the study, $L$. pneumophila was 6.3 times higher $\left(1.1 \times 10^{5}\right.$ gene copies $/ \mathrm{mL}$ ) in the low-use relative to high-use distal taps (a factor of 6.3) (Kruskal-Wallis Test, $p$ value $=0.004$ ), suggesting that differences induced by water use frequency became more pronounced as the microbial ecology of the systems matured. In contrast, L. pneumophila levels were relatively stable with time in the recirculating portions of the system (Table 3; Fig. 3, Kruskal-Wallis test, $p$ value $=0.22-0.40 ; n=6$ per sampling event). Consistent with the nutrient delivery hypothesis, this suggests that a stable microbial ecology may take longer to establish at the tap, where flow is intermittent, than in a continuously flowing system. A random survey of 452 household hot water systems also suggests that it may take time for Legionella to colonize new pipes, where it was found that homes with new plumbing systems (<2 years old) had no Legionella spp.-positive samples while $14 \%$ of older homes were colonized [25].

\section{L. pneumophila in the experimental system at moderate temperature $\left(51^{\circ} \mathrm{C}\right)$ (condition II)}

A major finding of this study may best be described as an ecological "sweet spot" that occurred when the water heater was set at $51{ }^{\circ} \mathrm{C}$ and the water use frequency was low. In this specific condition, enrichment of L. pneumophila at the tap relative to the recirculating line was striking (68.2 times higher; Fig. 4b). Interestingly, $L$. pneumophila concentrations decreased at the tap as expected in the medium- and high-use scenarios relative to both low use and the recirculating lines as the temperature was elevated to $51{ }^{\circ} \mathrm{C}$ (Fig. 4a, b), suggesting a unique phenomenon when a moderate water heater temperature is combined with low water use frequency. Besides being enriched relative to the recirculating line, L. pneumophila under the $51{ }^{\circ} \mathrm{C} /$ low-use condition was also uncharacteristically high in concentration (Fig. 4a), equivalent to that of the control system maintained at optimal growth temperature (KruskalWallis test, $p$ value $=1.0$ ), and was the only case where low-use distal taps yielded greater total $L$. pneumophila than high-use distal taps (Fig. 4c, by a factor of 5, Kruskal-Wallis test, $p$ value $=0.044)$. We 
hypothesize that a brief exposure to a sub-optimal disinfection temperature (i.e., Fig. 2) combined with sufficient stagnation time for recovery and re-growth can lead to selection of L. pneumophila at the tap. Others have also noted evidence that brief exposures to elevated temperatures could have unintended negative consequences by decreasing competition or enhancing nutrient availability via necrotrophic growth $[33,34]$, and rapid recolonization after thermal disinfection has been observed in the field [35]. Importantly, new guidelines on effective control of Legionella in building systems suggest maintaining at least $51{ }^{\circ} \mathrm{C}$ in all portions of the hot water system $[18,22]$. It is apparent from these results that it will be difficult (if not impossible) to maintain set point temperatures throughout distal portions of the system (Fig. 2; Additional file 1: Figure S2) and may inadvertently increase Legionella risk under certain circumstances. The $51{ }^{\circ} \mathrm{C}$ sweet spot warrants further investigation.

\section{L. pneumophila in the experimental system at high temperature $\left(58^{\circ} \mathrm{C}\right)$ (condition III)}

While elevating the water heater temperature to $58{ }^{\circ} \mathrm{C}$ effectively eliminated the selective effect of the $51{ }^{\circ} \mathrm{C} /$ low-use condition, the advantages were not striking in terms of L. pneumophila concentrations (Fig. 4a) or yields (Fig. 4c) in medium- or high-use distal taps relative to 42 or $51{ }^{\circ} \mathrm{C}$. Nevertheless, the advantages of elevated water heater temperature were clear when comparing the experimental to the control system (Fig. 4; $40-50$ times reduction in total weekly yield at 58 versus $39{ }^{\circ} \mathrm{C}$ ), suggesting that the gradual L. pneumophila colonization of both systems with time may have muted the benefits of the elevated temperature. Further, $L$. pneumophila tended to be positively selected at the tap in the control system (Fig. 4b, ratios generally $>1.0$ ) and negatively selected at the tap in the experimental system at $58{ }^{\circ} \mathrm{C} /$ high-use frequency (Fig. $4 \mathrm{~b}$, ratios <1.0). This suggests that, if applied properly, elevated temperature can have a lasting effect for L. pneumophila control at the tap. Interestingly, the enhanced delivery hypothesis appeared to hold true as the temperature was elevated in the experimental system, with increased total yields of $L$. pneumophila as water use frequency increased (Fig. 4c). However, increased water use decreased L. pneumophila concentrations by a factor of 5.0 relative to lower use in the experimental system at $58{ }^{\circ} \mathrm{C}$ (Fig. 4a).

\section{Microbial ecological relationships of $L$. pneumophila in hot water plumbing}

\section{Trends in biofilm-associated L. pneumophila}

We repeatedly swabbed the same area $\left(65 \mathrm{~cm}^{2}\right)$ to collect biofilm at the end of each experimental period, providing a measurement of $L$. pneumophila that re- colonized pipe surfaces at each temperature setting (Fig. 5). L. pneumophila in influent pipe biofilms was consistently below the detection limit, except for the 11-month sampling date (Fig. 5a, during a period of elevated influent water temperature of $22-23$ versus $11-13{ }^{\circ} \mathrm{C}$ for subsequent sampling events), further lending confidence that $L$. pneumophila gene copies observed in the plumbing systems were representative of re-growth and not an artifact of the influent. Interestingly, L. pneumophila levels were consistently below detection in the recirculating pipe biofilm of the experimental system when the water heater setting was $\geq 48{ }^{\circ} \mathrm{C}$, while they consistently increased with time in the control rig set to $39^{\circ} \mathrm{C}$ (Fig. 5a). Thus, it appears that L. pneumophila was not adept at re-colonizing biofilms at moderate-high water heater temperature set points, though it cannot be certain how it behaved in intact portions of the biofilm not subject to re-sampling.

Water use frequency also appeared to affect re-growth of biofilm-associated L. pneumophila. For example, in the control system biofilm, L. pneumophila increased with increased use frequency, with 55 times more $L$. pneumophila in the continuously recirculating line than the most frequently used distal taps by the end of the study (Fig. 5 a versus 5 b). This is consistent with the nutrient delivery hypothesis [23]. However, where there was a trend in the experimental system, it was the opposite, with 19.2 times less biofilm-associated L. pneumophila in high-use distal taps than low-use taps when the heater was set at $51{ }^{\circ} \mathrm{C}$ (Fig. 5b, Kruskal-Wallis test, $p$ value $=0.037, n=12$ ). Notably, this was also the ecological sweet spot condition noted above, suggesting the brief exposure to sub-optimal disinfection temperature followed by long stagnation selected for L. pneumophila in the biofilm as well as the bulk water. Although water use frequency can be subordinate to other factors, such as temperature and corresponding microbial ecological responses, analyzing water use conditions in conjunction with water temperature helps reconcile discrepancies in prior reports of effects of stagnation on L. pneumophila $[15,23,25]$.

\section{Relationships among L. pneumophila and other ecologically relevant microorganisms}

Relationships were explored among total bacteria, Legionella spp., and $V$. vermiformis to gain insight into how $L$. pneumophila behaved in the context of the broader plumbing microbiome (Figs. 6 and 7). Remarkably, elevated temperatures did not have a significant effect on the levels of total bacteria in the recirculating lines or at the tap (Kruskal-Wallis test, $p$ value $=0.27, n=58$ ). While it was expected that the disinfecting properties of the hotter water would reduce total microbial populations, our results suggest that instead the elevated temperature merely 

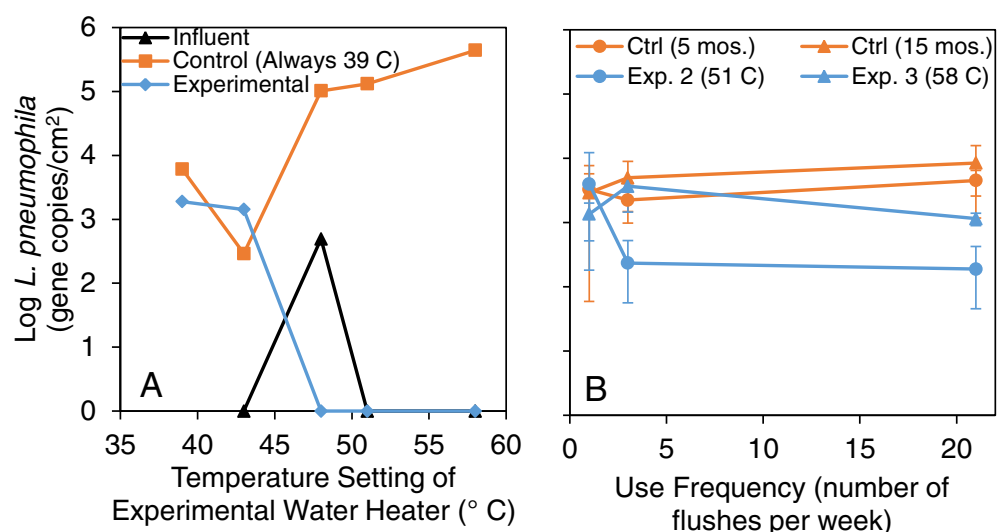

Fig. 5 Biofilm-associated L. pneumophila concentrations. a L. pneumophila concentrations in recirculating lines as a function of water heater temperature setting. The $x$-axis reports the temperature setting for the experimental water heater, with the corresponding values for the control and influent plotted for the same time point. The control system remained at $39{ }^{\circ} \mathrm{C}$ throughout the experiment. No error bars were calculated due to the biofilm sampling approach used. $\mathbf{b}$ L. pneumophila concentrations at the distal taps as a function of flush frequency. Error bars indicate $95 \%$ confidence intervals on biological replicate samples $(n=6)$. Note that biofilms were subject to repeated sampling of the same area; thus, the numbers represent re-growth between sampling events

shifted the microbiome composition, which can be seen by reductions in the other specific targets in the experimental relative to the control system (Figs. 6 and 7).

Of particular interest was the relationship between Legionella and $V$. vermiformis, which is among freeliving amoebae thought to act as obligate hosts for Legionella replication in drinking water systems and thus could be an important player in pathogen control $[27,36,37]$. While there is a broad range of known amoeba hosts for Legionella, $V$. vermiformis was chosen as the focus of this work because it is among the most frequently detected Legionella host organisms in drinking water [38-40] and was found to be the most prevalent amoebae (and weakly correlated to Legionella spp.) in a prior investigation of Blacksburg, VA, tap water [36]. Here, we found that Legionella spp. and L. pneumophila were correlated with $V$. vermiformis under certain circumstances. During the baseline sampling, when the microbial community was still developing, there were no correlations between $V$. vermiformis and Legionella spp. or L. pneumophila (Spearman rank correlations, rho $=-0.19-0.47, p$ value $=0.15-0.47)$. However, later in the experiment (13 months), significant correlations developed in the distal pipes in the mature experimental system set to $51{ }^{\circ} \mathrm{C}$ (Spearman rank correlation, rho $=0.52-$ $0.68, p$ value $=0.002-0.031$ ). This suggests that $V$. vermiformis may have played a role in the much higher levels of L. pneumophila observed in the water- and biofilmassociated L. pneumophila as thermal stresses reached the sweet spot in the experimental system at $51{ }^{\circ} \mathrm{C}$ (Fig. 4b, c). While correlations did occasionally exist in the recirculating line samples, seven of eight correlations of $V$. vermiformis compared to Legionella spp. and L. pneumophila during the last two sampling periods were inconsistent and insignificant (Spearman rank correlation, rho $=$ $0.02-0.70, p$ value $=0.19-0.95$ ). Lack of a consistent correlation suggests a dynamic relationship between $V$. vermiformis and Legionella, which is intuitive given their predator-prey relationship.

\section{Relationship between Legionella spp. and L. pneumophila}

The genus Legionella contains other pathogens, besides L. pneumophila, as well as non-pathogenic members. Thus, there is interest in how L. pneumophila behaves in hot water systems relative to Legionella spp. L. pneumophila and Legionella spp. were strongly correlated across all water samples $\left(R^{2}=0.70, n=484\right)$ and across all distal tap water samples $\left(R^{2}=0.75, n=357\right)$, but in most other cases, correlations were weak (e.g., $R^{2}=$ $0.57, \mathrm{n}=90$ ) in water samples of recirculating lines or non-existent. This indicates that there are situations under which L. pneumophila trends with other Legionella spp. and other cases where it does not. In particular, we observe an apparent decrease in the ratio of $L$. pneumophila to Legionella spp. with elevated temperature. For instance, when the temperature of the experimental system was increased to 48 or $58{ }^{\circ} \mathrm{C}$ (but not $51{ }^{\circ} \mathrm{C}$ possibly due to the unique selective condition), the ratio of L. pneumophila to Legionella spp. was significantly lower in the experimental than in the control system (paired $t$ test, $p$ value $<0.0001, n=36-$ 48). While temperature may truly be the dominating factor influencing the type of Legionella that prevails, other selectors have been noted in the literature, such as other microorganisms (e.g., Bacillus subtilis) inhibiting L. pneumophila growth within amoeba or lysing cells [34, 41, 42]. 


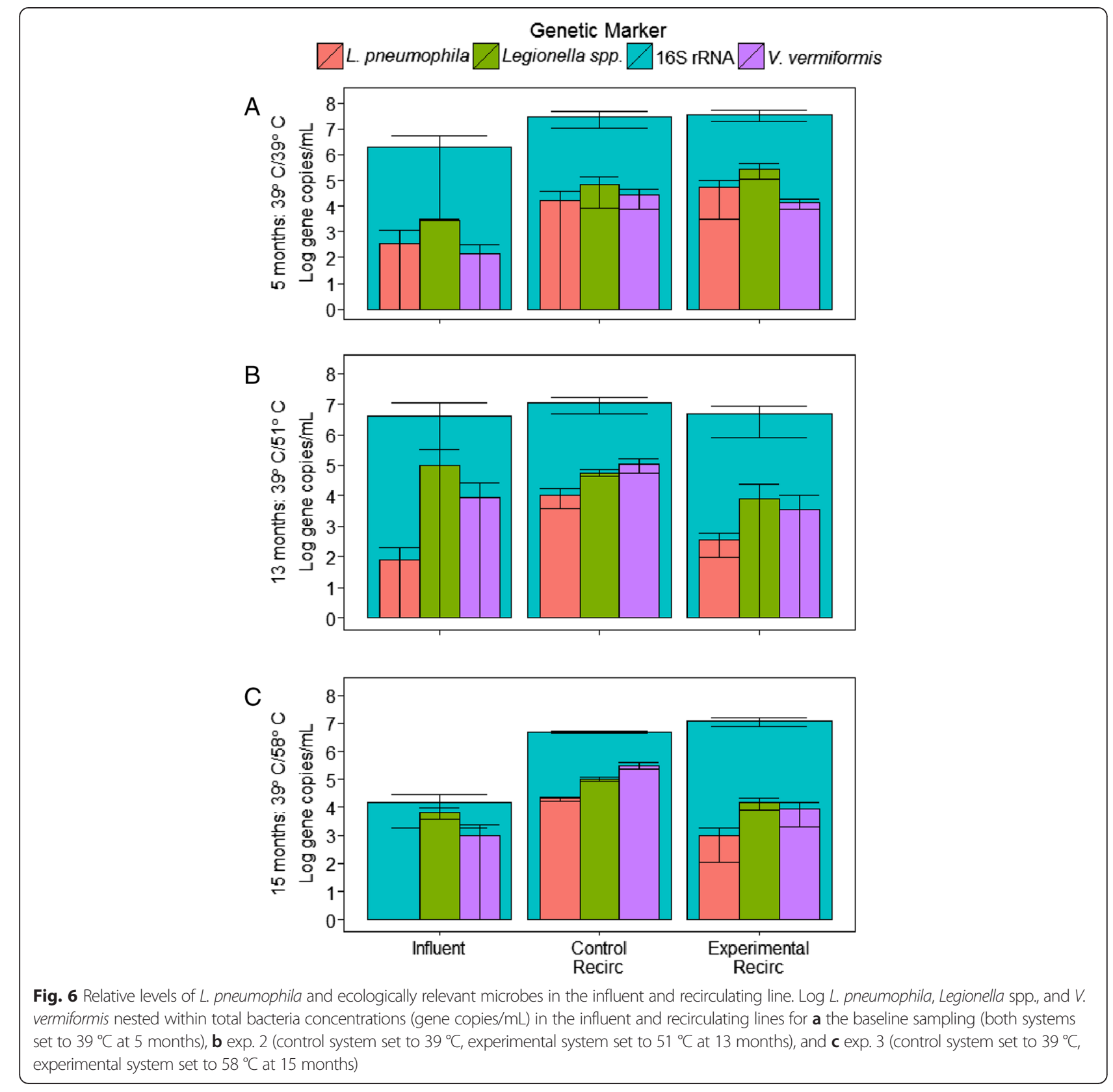

\section{Survival of L. pneumophila at elevated temperatures}

Importantly, this study demonstrated that, even at the highest temperature of $58{ }^{\circ} \mathrm{C}, \mathrm{L}$. pneumophila was not eliminated from the hot water plumbing and continued to persist at levels greater than the influent (Fig. 3). We did not expect this result given that it is thought that $L$. pneumophila is unable to replicate above $50{ }^{\circ} \mathrm{C}$ [49-53], though it has been observed to survive short periods of time at $55-70{ }^{\circ} \mathrm{C}$ and long periods (on the order of months) as free organism in hot spring water [43-51]. Nonetheless, our work is strongly suggestive that $L$. pneumophila growth does occur in this temperature range under representative plumbing conditions. Given that $99.97 \%$ (3 logs) of planktonic L. pneumophila would theoretically be washed out of both systems each week, re-growth is the most likely explanation for the persistence observed at elevated temperature. Even though biofilm-associated L. pneumophila was shown to not be able to re-colonize the swabbed areas at higher temperatures, it is possible that L. pneumophila persisted in and was released from the vast majority of the biofilm not disturbed by sampling, perhaps within amoebae hosts. Notably, high levels of planktonic $V$. vermiformis was detected at $58{ }^{\circ} \mathrm{C}$ (Fig. 6, average of $8.4 \times 10^{3}$ gene copies $/ \mathrm{mL}$ ), which could extend the range at which L. pneumophila grows $[14,52]$. 

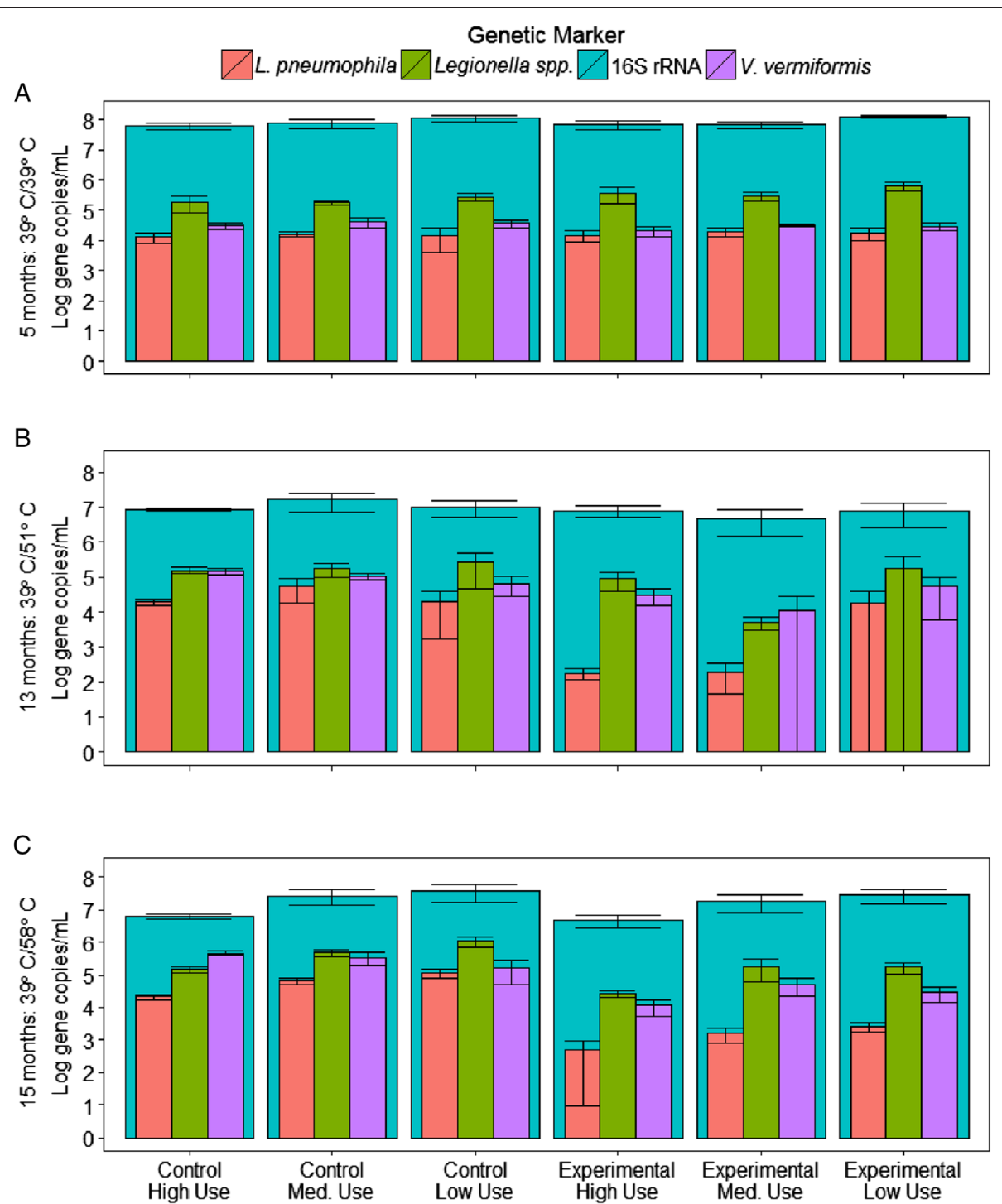

Fig. 7 Relative levels of L. pneumophila and ecologically relevant microbes in the distal taps. Log L. pneumophila, Legionella spp., and V. vermiformis nested within total bacteria concentrations (gene copies $/ \mathrm{mL}$ ) in the distal taps for each water use frequency for a the baseline sampling (both systems set to $39^{\circ} \mathrm{C}$ at 5 months), $\mathbf{b} \exp .2$ (control system set to $39^{\circ} \mathrm{C}$, experimental system set to $51^{\circ} \mathrm{C}$ at 13 months), and $\mathbf{c}$ exp. 3 (control system set to $39^{\circ} \mathrm{C}$, experimental system set to $58^{\circ} \mathrm{C}$ at 15 months)

\section{Conclusions}

Here, we examined the effect of water heater temperature setting and water use frequency, which are two critical factors for energy and water conservation, on L. pneumophila as a representative OP resident to the building plumbing microbiome. This controlled, replicated, pilotscale approach aided in resolving complexities encountered in prior field studies and addressing discrepancies with respect to effects of temperature and stagnation reported in the literature. Overall, it was found that elevated temperature was a critical factor in suppressing $L$. pneumophila growth both in continuously recirculating hot water lines and at the tap, where water quickly cools to room temperature following heat shock. Nonetheless, naturally occurring L. pneumophila persisted up to $58^{\circ} \mathrm{C}$, with strong evidence for growth within this pilot-scale plumbing system, relative to prior understanding that it does not grow above $50{ }^{\circ} \mathrm{C}$ under simplified laboratory conditions. Further, it was found that temperature and water use frequency can have interactive effects; for example, optimal L. pneumophila selection at the tap was observed when the water use frequency was low following a heat shock at $51{ }^{\circ} \mathrm{C}$. At the same time, while higher use frequency can dilute L. pneumophila and result in lower concentrations at the tap, it still tended to result in higher overall yields, given that concentration is multiplied by higher use frequency. We hypothesize that increased water use frequency replenishes nutrients required for $L$. 
pneumophila re-growth and delivers a measurable $L$. pneumophila population to distal taps, where temperature conditions remain suitable for L. pneumophila re-growth or persistence. Overall, this study takes a step towards untangling the complexity of the factors shaping the microbial ecology of hot water plumbing and lays the groundwork for an integrated approach for opportunistic pathogen control.

\section{Methods}

\section{Experimental setup and operation}

Two identical household hot water systems with 71.9-L (19 gallons) electric water heaters and continuously recirculating pipe loops were constructed with nominal 3/4-in. chlorinated polyvinyl chloride (CPVC; Charlotte Pipe, Charlotte, NC) pipe (Fig. 1). Each system tested two pipe orientations (upward/downward) with three water use patterns in triplicate, including low use (1 flush/week), medium use (3 flushes/week), and high use (21 flushes/week) for a total of 36 distal taps (2 systems $\times 2$ orientations $\times 3$ use patterns $\times$ triplicate $=36$ ) . Each distal tap pipe was $1.7 \mathrm{~m}(5.5 \mathrm{ft})$ for a total distal tap volume of $0.43 \mathrm{~L}$ (0.11 gallons) and internal surface area of $0.87 \mathrm{~m}^{2}\left(0.94 \mathrm{ft}^{2}\right)$. Each recirculating line was a total of $7.6 \mathrm{~m}(25 \mathrm{ft})$. The water heaters and recirculating lines were completely mixed, resulting in a combined volume of $73.9 \mathrm{~L}$ (19.5 gallons) and surface area of $1.46 \mathrm{~m}^{2}\left(15.7 \mathrm{ft}^{2}\right)$. Each flush was conducted for $28 \mathrm{~s}$ at $3.8 \mathrm{~L} / \mathrm{min}$ (1 gallon/min). Influent water consisted of wellflushed (10 $\mathrm{min}$ at $11.3 \mathrm{~L} / \mathrm{min}$ ), granular activated carbon (GAC)-filtered Blacksburg, VA, tap water. Both systems were initially acclimated for 5 months at $39{ }^{\circ} \mathrm{C}$. Afterwards, the experimental system water heater temperature was increased approximately by $5{ }^{\circ} \mathrm{C}$ increments while the control system remained at $39{ }^{\circ} \mathrm{C}$. During periods of stagnation, distal pipes cooled to room temperature.

\section{Water quality analysis}

Disinfectant residual, total ammonia, temperature, $\mathrm{pH}$, dissolved oxygen (DO), total organic carbon (TOC), and total and dissolved cations were generally characterized at each temperature setting beginning 1 week after each temperature adjustment. Chloramine and total ammonia were measured according to Standard Method 4500$\mathrm{Cl} 25$ and 5310-NH3 using a DR2700 or DR5000 spectrophotometer (HACH, Loveland, $\mathrm{CO}) . \mathrm{pH}$ and temperature were measured using a $\mathrm{pH} 110$ meter with automatic temperature correction (Oakton Research, Vernon Hills, IL). DO was monitored using a Thermo Scientific Orion 3-star meter. TOC was measured by persulfate-ultraviolet detection using a Sievers Model $5300 \mathrm{C}$ with an autosampler according to Standard Method 5310 C. Cations were measured by inductively coupled plasma mass spectrometry after acidification with $2 \%$ nitric acid $(v / v)$ and $>24$-h holding time.

\section{Microbiological sample collection and DNA extraction}

After a minimum of 2-month acclimation period at each experimental condition, approximately $0.5 \mathrm{~L}$ of firstflush water was collected directly from the influent, recirculating lines, and each distal tap at the end of regular stagnation periods for each use condition and filtered through sterile $0.22-\mu \mathrm{m}$ pore-size mixed cellulose ester filters (Millipore, Billerica, MA). Filters were fragmented and subjected to DNA extraction. For biofilm sampling, $65 \mathrm{~cm}^{2}$ of the influent, recirculating line, and ends of the distal tap pipes accessible by threaded union connections were swabbed using sterile cotton-tip applicators (Fisherbrand, Fisher Scientific, UK). DNA was extracted directly from the fragmented filters and cotton swabs using a FastDNA Spin Kit (MP Biomedicals, Solon, $\mathrm{OH}$ ) according to the manufacturer protocol. Field, trip, and equipment negative controls consisting of pre-sterilized water in identical sampling bottles were included each time samples were collected.

\section{Quantitative polymerase chain reaction}

Gene markers for Legionella spp., L. pneumophila, and $V$. vermiformis, along with bacterial $16 \mathrm{~S}$ rRNA genes, were enumerated by quantitative polymerase chain reaction (q-PCR) assays using previously established methods [42]. In brief, all q-PCR assays were performed in $10 \mu \mathrm{L}$ reaction mixtures containing SsoFast Probes or Evagreen Supermix (Bio-Rad, Hercules, CA), 250 or $400 \mathrm{nM}$ primer, and $93.75 \mathrm{nM}$ probe (Taqman assay only) with $1 \mu \mathrm{L}$ of DNA template. DNA extracts (diluted $1: 10$ to minimize inhibition), a negative control, 10 -fold serial dilutions of standards, and a positive spike into sample DNA matrix were included in triplicate wells with each q-PCR run. The quantification limit (QL) for all q-PCR assays ranged from 10 to 1000 gene copies/reaction and was implemented as appropriate for each run. Samples yielding threshold cycles $\geq$ QL in at least two q-PCR triplicate wells were considered quantifiable. Samples with only one triplicate above the QL threshold cycle or samples otherwise below the QL were reanalyzed undiluted to increase the QL of the assays. On each re-run plate, standard DNA template was spiked into the experimental DNA matrix to confirm that amplification reactions were not inhibited in undiluted samples. If inhibited, the sample was marked as below the QL. All values are reported as $\log ($ gene copies $/ m L+1)$.

\section{Statistical analyses}

All error bars on figures and \pm calculations are $95 \%$ confidence intervals, calculated based on the normal cumulative distribution function, degrees of freedom, and standard error. For graphing and statistical purposes, any positive detection below q-PCR QL was entered as half of the quantification limit. All data exploration was 
conducted in Microsoft Excel 2013 or JMP Pro 11. Spearman's rank coefficient and associated significance tests were conducted in JMP Pro 11 to detect and quantify relationships between gene markers (using "Multivariate Methods"). Other statistical tests were performed using RStudio with $\mathrm{R}$ version 3.2.0. Student's $t$ test ("t.test()") and Kruskal-Wallis tests with a Holm $p$ value adjustment for multiple comparisons were conducted to compare sample means (initially with "kruskal.test()," then using package and function "dunn.test()" for multiple comparisons). Significance was determined at $p=$ 0.05 .

\section{Additional files}

Additional file 1: Tables S1-S3 and Figures S1-S8. This contains Tables S1-S3 and Figures S1-S8 [45-59]. (DOCX $77.1 \mathrm{~kb})$

Additional file 2: Correlation Analysis. This contains all correlations analyses of quantitative polymerase chain reaction assays. (XLSX $24.2 \mathrm{~kb}$ )

\section{Competing interests}

The authors declare that they have no competing interests.

\section{Authors' contributions}

WJR designed, built, and maintained the experiment; collected (and prepared) the samples for analysis; performed the chemical/physical analyses; analyzed the data; constructed all the tables and figures; performed all the statistical analyses; and drafted the manuscript. PJ performed the q-PCR assays and provided feedback on the manuscript. AP and MAE designed the experiment, assisted in the data analysis approach, and revised the manuscript. All authors read and approved the final manuscript.

\section{Acknowledgements}

We would like to thank the Alfred P. Sloan Foundation Microbiology of the Built Environment Program and the National Science Foundation (CBET Award \# 1336650) for financially supporting this project. We would also like to thank Christina Swann, Kelly Peterson, Arjan Ahluwalia, Myra Williams, Ni (Joyce) Zhu, Jeffery Parks, and Daniel Logsdon for their technical and laboratory assistance.

Received: 14 September 2015 Accepted: 17 November 2015 Published online: 01 December 2015

\section{References}

1. Pruden A, Edwards MA, Falkinham, III JO. Research needs for opportunistic pathogens in premise plumbing: experimental methodology, microbial ecology and epidemiology. Water Research Foundation Project 4379. 2012. http://www.waterrforg/PublicReportLibrary/4379.pdf. Accessed 12 Sept 2015.

2. Bartrand TA, Causey JJ, Clancy JL. Naegleria fowleri: an emerging drinking water pathogen. JAWWA. 2014;106:10.

3. Falkinham JO. Common features of opportunistic premise plumbing pathogens. Int J Environ Res Public Health. 2015;12(5):4533-45.

4. Bédard E, Fey S, Charron D, Lalancette C, Cantin P, Dolcé P, et al. Temperature diagnostic to identify high risk areas and optimize Legionella pneumophila surveillance in hot water distribution systems. Water Res. 2015; 71:244-56.

5. Yoder J, Roberts V, Craun GF, Hill V, Hicks L, Alexander NT, et al. Surveillance for waterborne disease and outbreaks associated with drinking water and water not intended for drinking - United States, 2005-2006. MMWR Surveill Summ. 2008;57(SS09):39-62.

6. Brunkard JM, Ailes E, Robers VA, Hill V, Hilborn ED, Craun GF, et al. Surveillance for waterborne disease and outbreaks associated with drinking water and water not intended for drinking - United States, 2007-2008. MMWR Surveill Summ. 2011;60(SS12):38-68.
7. Berry D, Xi C, Raskin L. Microbial ecology of drinking water distribution systems. Curr Opin Biotechnol. 2006;17(3):297-302.

8. Camper AK, LeChevallier MW, Broadaway SC, McFeters GA. Growth and persistence of pathogens on granular activated carbon filters. Appl Environ Microbiol. 1985;50(6):1378-8.

9. Chiao TH, Clancy TM, Pinto A, Xi C, Raskin L. Differential resistance of drinking water bacterial populations to monochloramine disinfection. Environ Sci Technol. 2014;48(7):4038-47.

10. Feazel LM, Baumgartner LK, Peterson KL, Frank DN, Harris JK, Pace NR. Opportunistic pathogens enriched in showerhead biofilms. Proc Natl Acad Sci. 2009;106(38):16393-9.

11. Straus WL, Plouffe JF, File TM, Lipman HB, Hackman BH, Salstrom SJ, et al. Risk factors for domestic acquisition of Legionnaires disease. Arch Intern Med. 1996;156(15):1685-92

12. Alary M, Joly JR. Risk factors for contamination of domestic hot water systems by legionellae. Appl Environ Microbiol. 1991;57(8):2360-7.

13. Borella P, Montagna MT, Romano-Spica V, Stampi S, Stancanelli G, Triassi M, et al. Legionella infection risk from domestic hot water. Emerg Infect Dis, 2004;10(3):457.

14. Storey MV, Ashbolt NJ, Stenström TA. Biofilms, thermophilic amoebae and Legionella pneumophila - a quantitative risk assessment for distributed water. Water Sci Technol. 2004;50(1):77-82.

15. Ciesielski CA, Blaser MJ, Wang WL. Role of stagnation and obstruction of water flow in isolation of Legionella pneumophila from hospital plumbing. Appl Environ Microbiol. 1984;48(5):984-7.

16. Harper D. Legionnaires' disease outbreaks —-the engineering implications. J Hosp Infect. 1988;11:201-8.

17. OSHA technical manual. Section III: Chapter 7. Legionnaires' disease. https:// www.osha.gov/dts/osta/otm/otm_iii/otm_iii_7.html. Accessed 12 Sept 2015.

18. ASHRAE Guideline 12-2000. Minimizing the risk of legionellosis associated with building water systems. 2000.

19. Health and safety executive. Legionella and Legionnaires' disease. http:// www.hse.gov.uk/legionnaires/ Accessed 12 Sept 2015.

20. Muraca P, Stout JE, Yu VL. Comparative assessment of chlorine, heat, ozone, and UV light for killing Legionella pneumophila within a model plumbing system. Appl Environ Microbiol. 1987:53(2):447-53.

21. Stout JE, Victor LY, Muraca P. Legionnaires' disease acquired within the homes of two patients: link to the home water supply. JAMA. 1987;257(9):1215-7.

22. AMSI/ASHRAE Standard 188-2015. Legionellosis: risk management for building water systems. Atlanta, GA. 2015.

23. Liu Z, Lin YE, Stout JE, Hwang CC, Vidic RD, Yu VL. Effect of flow regimes on the presence of Legionella within the biofilm of a model plumbing system. J Appl Microbiol. 2006;101(2):437-42.

24. Moore MR, Pryor M, Fields B, Lucas C, Phelan M, Besser RE. Introduction of monochloramine into a municipal water system: impact on colonization of buildings by Legionella spp. Appl Environ Microbiol. 2006;72(1):378-83.

25. Mathys W, Stanke J, Harmuth M, Junge-Mathys E. Occurrence of Legionella in hot water systems of single-family residences in suburbs of two German cities with special reference to solar and district heating. Int J Hyg Environ Health. 2008:211(1):179-85.

26. Ohl L, Horn $H$, Hempel D. Behaviour of biofilm systems under varying hydrodynamic conditions. Water Sci Technol. 2004:49(11-12):345-51.

27. Thomas JM, Ashbolt NJ. Do free-living amoebae in treated drinking water systems present an emerging health risk? Environ Sci Technol. 2010;45(3):860-9.

28. Lau HY, Ashbolt NJ. The role of biofilms and protozoa in Legionella pathogenesis: implications for drinking water. J Appl Microbiol. 2009; 107:368-78.

29. Nguyen C, Elfland C, Edwards MA. Impact of advanced water conservation features and new copper pipe on rapid chloramine decay and microbial regrowth. Water Res. 2012;46(3):611-21.

30. Elfland C, Scardina P, Edwards MA. Lead-contaminated water from brass plumbing devices in new buildings. JAWWA. 2010;102(11):66.

31. Environmental Protection Agency (EPA). Effects of water age on distribution system water quality. Office of Water. Office of Ground Water and Drinking Water. 2002. http://water.epa.gov/lawsregs/rulesregs/sdwa/tcr/upload/2007_ 05_18_disinfection_tcr_whitepaper_tcr_waterdistribution.pdf. Accessed 12 Sept 2015

32. Vasconcelos J. J, Boulos P. F. (1996). Characterization and modeling of chlorine decay in distribution systems. American Water Works Association. 
http://www.waterrf.org/ExecutiveSummaryLibrary/90705_815_profile.pdf. Accessed 13 Sept 2015.

33. Allegra S, Grattard F, Girardot F, Riffard S, Pozzetto B, Berthelot P. Longitudinal evaluation of the efficacy of heat treatment procedures against Legionella spp. in hospital water systems by using a flow cytometric assay. Appl Environ Microbiol. 2011;77(4):1268-75.

34. Temmerman R, Vervaeren H, Noseda B, Boon N, Verstraete W. Necrotrophic growth of Legionella pneumophila. Appl Environ Microbiol. 2006;72(6):4323-8.

35. Steinert M, Ockert G, Lück C, Hacker J. Regrowth of Legionella pneumophila in a heat-disinfected plumbing system. Zentralblatt für Bakteriologie. 1998; 288(3):331-42

36. Wang $\mathrm{H}$, Edwards $\mathrm{M}$, Falkinham JO, Pruden A. Molecular survey of the occurrence of Legionella spp., Mycobacterium spp., Pseudomonas aeruginosa, and amoeba hosts in two chloraminated drinking water distribution systems. Appl Environ Microbiol. 2012;78(17):6285-94.

37. Rowbotham TJ. Preliminary report on the pathogenicity of Legionella pneumophila for freshwater and soil amoebae. J Clin Pathol. 1980;33(12):1179-83.

38. Ovrutsky AR, Chan ED, Kartalija M, Bai X, Jackson M, Gibbs S, et al. Cooccurrence of free-living amoebae and nontuberculous Mycobacteria in hospital water networks, and preferential growth of Mycobacterium avium in Acanthamoeba lenticulata. Appl Environ Microbiol. 2013;79(10):3185-92.

39. Coşkun KA, Özçelik S, Tutar L, Elald N, Tutar Y. Isolation and identification of free-living amoebae from tap water in Sivas, Turkey. Bio Med Res Int. 2013. doi:10.1155/2013/675145.

40. Scheikl U, Sommer R, Kirschner A, Rameder A, Schrammel B, Zweimüller I, et al. Free-living amoebae (FLA) co-occurring with legionellae in industrial waters. Eur J Protistol. 2014;50(4):422-9.

41. Guerrieri E, Bondi M, Sabia C, de Niederhäusern S, Borella P, Messi P. Effect of bacterial interference on biofilm development by Legionella pneumophila. Curr Microbiol. 2008:57(6):532-6.

42. Wang $\mathrm{H}$, Edwards MA, Falkinham III JO, Pruden A. Probiotic approach to pathogen control in premise plumbing systems? A review. Environ Sci Technol. 2013;47(18):10117-28.

43. Fliermans CB, Cherry WB, Orrison LH, Smith SJ, Tison DL, Pope DH. Ecological distribution of Legionella pneumophila. Appl Environ Microbiol. 1981:41(1):9-16.

44. Sheehan KB, Henson JM, Ferris MJ. Legionella species diversity in an acidic biofilm community in Yellowstone National Park. Appl Environ Microbiol. 2005;71(1):507-11.

45. Ohno A, Kato N, Yamada K, Yamaguchi K. Factors influencing survival of Legionella pneumophila serotype 1 in hot spring water and tap water. Appl Environ Microbiol. 2003;69(5):2540-7.

46. Dennis PJL, Wright AE, Rutter DA, Death JE, Jones BPC. Legionella pneumophila in aerosols from shower baths. J Hyg. 1984;93(02):349-53.

47. Schulze-Röbbecke R, Rödder M, Exner M. Multiplication and killing temperatures of naturally occurring legionellas. Zentralblatt fur Bakteriologie, Mikrobiologie und Hygiene. 1987;184(6):495-500.

48. Darelid J, Löfgren S, Malmvall BE. Control of nosocomial Legionnaires' disease by keeping the circulating hot water temperature above $55 \mathrm{C}$ : experience from a 10-year surveillance programme in a district general hospital. J Hosp Infect. 2002;50(3):213-9.

49. Söderberg MA, Rossier O, Cianciotto NP. The type II protein secretion system of Legionella pneumophila promotes growth at low temperatures. J Bacteriol. 2004;186(12):3712-20.

50. Wadowsky RM, Yee RB. Glycine-containing selective medium for isolation of Legionellaceae from environmental specimens. Appl Environ Microbiol. 1981:42(5):768-72.

51. Wadowsky RM, Wolford R, McNamara AM, Yee RB. Effect of temperature, pH, and oxygen level on the multiplication of naturally occurring Legionella pneumophila in potable water. Appl Environ Microbiol. 1985;49(5):1197-205.

52. Kuchta JM, Navratil JS, Shepherd ME, Wadowsky RM, Dowling JN, Yee RB. Impact of chlorine and heat on the survival of Hartmannella vermiformis and subsequent growth of Legionella pneumophila. Appl Environ Microbiol. 1993:59(12):4096-100.

53. Schulze-Röbbecke R, Buchholtz KATRIN. Heat susceptibility of aquatic mycobacteria. Appl Environ Microbiol. 1992;58(6):1869-73.

54. Wallace Jr RJ, Brown BA, Griffith DE. Nosocomial outbreaks/pseudo outbreaks caused by nontuberculous mycobacteria. Ann Reviews Microbiol. 1998:52(1):453-90.

55. Anand CM, Skinner AR, Malic A, Kurtz JB. Interaction of L. pneumophila and a free living amoeba (Acanthamoeba palestinensis). J Hyg. 1983;91(02):167-78.
56. Buse HY, Ashbolt NJ. Differential growth of Legionella pneumophila strains within a range of amoebae at various temperatures associated with in-premise plumbing. Lett Appl Microbiol. 2011;53(2):217-24.

57. Nagington J, Smith DJ. Pontiac fever and amoebae. Lancet. 1980; 316(8206):1241.

58. Brown AD. Some general properties of a psychrophilic pseudomonad: the effects of temperature on some of these properties and the utilization of glucose by this organism and Pseudomonas aeruginosa. J Gen Microbiol. 1957;17(3):640-8

59. Van der Kooij D, Oranje JP, Hijnen WA. Growth of Pseudomonas aeruginosa in tap water in relation to utilization of substrates at concentrations of a few micrograms per liter. Appl Environ Microbiol. 1982;44(5):1086-95.

\section{Submit your next manuscript to BioMed Central and we will help you at every step:}

- We accept pre-submission inquiries

- Our selector tool helps you to find the most relevant journal

- We provide round the clock customer support

- Convenient online submission

- Thorough peer review

- Inclusion in PubMed and all major indexing services

- Maximum visibility for your research

Submit your manuscript at www.biomedcentral.com/submit 